\title{
Technology and Corporate Social Responsibility
}

\author{
Vojko Potocan
}

check for updates

Citation: Potocan, V. Technology and Corporate Social Responsibility. Sustainability 2021, 13, 8658. https://doi.org/10.3390/su13158658

Academic Editor: Giuliana Birindelli

Received: 4 July 2021

Accepted: 31 July 2021

Published: 3 August 2021

Publisher's Note: MDPI stays neutral with regard to jurisdictional claims in published maps and institutional affiliations.

Copyright: (C) 2021 by the author. Licensee MDPI, Basel, Switzerland. This article is an open access article distributed under the terms and conditions of the Creative Commons Attribution (CC BY) license (https:/ / creativecommons.org/licenses/by/ $4.0 /)$.
Faculty of Economics and Business, University of Maribor, Razlagova 14, 2000 Maribor, Slovenia; vojko.potocan@um.si; Tel.: +386-2-22-90-255

\begin{abstract}
This study examined the importance of technologies in advancing modern organizations' corporate social responsibility (CSR). Drawing upon environmentalist and technological theories, we analyzed the shift from the traditional development of technology to the development of sustainable technologies for the further sustainable advancement of organizations. Technology has decisively influenced the development of humankind, but its research has traditionally excluded sustainable development issues. Newer technological visions have addressed the incorporation of technologies in all industries more comprehensively to solve social issues related to environmental protection and sustainable economic development. Such an orientation is followed by several conceptual solutions, such as the sustainable use of traditional technologies, development of sustainable technologies, and interdisciplinary treatment of sustainable technology to extend the CSR model. The results of our study have theoretical implications, highlighting the effects of technological development and new technologies on the course of further societal sustainable development. Practical implications include extending CSR's Triple Bottom model with a technological dimension to improve organizations' further sustainable operating and behavior.
\end{abstract}

Keywords: sustainable development; tradition technology; newest technologies; sustainable technologies; corporate social responsibility; sustainable organizations

\section{Introduction}

The study examined the importance of technology in the responsible development of humankind by analyzing the effect of differently sustainable technologies on the corporate social responsibility (CSR) of modern organizations.

Media headlines on "questionable technological development" and "neglect of societal influences of technology" continue to worsen public opinion about the contribution of technological development and new technologies to the sustainable development of society [1,2].

Technological progress has been the basic driver of development throughout human history, contributing decisively to the entire development of humanity [3]. At the same time, the development of technology has been traditionally oriented toward breakthrough technological goals and mostly considered separately from increasingly demanding social issues in society [4]. Modern technological visions, among others, "Industry 4.0," "Industrial Internet scheme," and "Made in China 2025" [5], broadened the understanding of relations between technological and social issues in humankind development. In recent decades, researchers have paid more attention to the importance of technology for nature protection and the economic results of society, but technological development still focuses primarily on achieving technological goals and remains separate from the research of social development in social sciences [6].

The discrepancy between the current orientation of technological development and the needs of society to address pressing social issues raises the question of the need to change and balance the fundamental objectives of society as a whole, including the need to rethink technological developments for the needs of the future society [7]. 
The growing effect of humans on Earth has attracted scholars and professionals "interest for the society stakeholders" responsibilities for nature and the community [8] and caused the development of several solutions for more responsible operating and behavior of society such as responsible development, sustainable development, and social responsibility from the 1960s onwards [9]. These development concepts have been shaped by the need for more responsible actions and behavior at all levels of human existence, focusing on development: "intended for shaping humans' actions and policies oriented towards achieving responsible natural, social and economic goals of society" ([7], p. 857) which requires "balancing social and technological development in achieving responsible advancement of modern society" ([8], p. 271).

The idea of a responsible society has become more widespread since the 1970s [7] and from then, organizations have paid more attention to their social responsibility beyond only making profits for shareholders [9]. Such interests of organizations initiated development of the concept of corporate social responsibility (CSR), which comprehensively directs organizational reality for ensuring responsible care of organizations for achieving their natural, social, and economic goals [10] and harmonization of organizational goals with goals of responsible development of society [8]. In addition, scholars established "guidance for conceptual frameworks and methods for addressing the management, organization, and societal challenges in CSR practices" ([8], p. 271). The development of the CSR concept was led mainly by social scientists, so other areas and aspects of addressing sustainable development were less discussed and included in the CSR model only indirectly as external factors or a framework for considering CSR [11].

Such a situation raises the question of how to consider and further integrate nonsocial issues, particularly the role and importance of technology in achieving CSR [6], in addressing sustainable development of society [8].

The links between technological development and sustainable development are less studied [12], mainly because of the still prevailing monodisciplinary treatment of sustainable issues among researchers from different scientific disciplines [13]. While social scholars suggest several methodological and contextual ideas for the potential use of technological solutions in sustainable development [6], the effects of new technologies on society and ways of technology support of sustainability development in modern society are less studied [4]. Thus, the literature reported about individual attempts to study their past interconnections more comprehensively such as use of sociotechnical theory $[6,8]$ and the several systems theories [14].

With the emergence of new technological visions, the links between technology and sustainability have become more frequently addressed [12]; however, a mono-disciplinary research approach and differences in research interests between technological and social researchers hinder the significant progress in understanding this issue $[12,14]$.

This raises questions about the influence of technological development and new technologies on CSR and organizations [7,15], directions and strength of correlations between technology and CSR in organizations [12,14], or even about the possibility of contextual inclusion of technology in CSR [1,11].

To give our study analytical traction, we focusing our analysis on goals related with the meaning of technology for organizations' CSR, as suggest several prior studies [12,16]. The first goal is analyzing the meaning of technology for social development with review of the past and present effects of technology on the responsible development of society [12] in the framework of the general societal development [16]. By investigation of the relations and effects of evolving technological development on societal development, we want to evaluate and assess the possible contribution of new technological visions and solutions for sustainable development of society in the future [13].

The second goal is analyzing how technology as a necessary framework and factor of development contributes to social development over time and presents possibilities for its support to future development [11]. Our research complements previous environmentalism studies $[6,12]$ by showing the different possibilities of addressing technology in the context 
of sustainable development [16] and analysis of the meaning of new technological visions and belonging technologies for more sustainable treatment of technology in CSR [5].

Third, we analyze the proposal to supplement the contextual treatment of CSR with the technological viewpoint of organizational operating and behavior [10]. By including technology in the business model of CSR, we extended the previous studies [6] by offering explanations and boundary conditions of a more systematic and holistic analysis of technology in CSR [10].

In the following sections of this paper, we first provide theoretical foundations for different approaches to understanding and addressing the relationship between technology development and corporate social responsibility. In this framework, we present the role of technology in social development and the importance of technology for corporate social responsibility as the most influential institutions of modern society. We continue by presenting the possible solutions for the broader inclusion of technology in corporate social responsibility with suggestions for shifting from the traditional support of technology for societal development to the possibility of using modern technological concepts to solve social problems related to environmental protection and sustainable economic development. We conclude the paper with a discussion of research results, a presentation of possible applications of research results, and possible directions for further studies.

\section{Theoretical Framework and Research Question}

\subsection{The Role of Technology in Societal Development}

Technological development and associated technologies decisively shaped the entire social development in the past $[12,14]$. Thus, technology has enabled and supported the development of different societies from (1) hunting society, which marked the birth of human beings and their living in coexistence with nature, (2) agrarian society from 13,000 BC onwards characterized by the development of irrigation techniques and establishment of settlements, (3) industrial society after the invention of the steam locomotive and start of mass production, (4) information society following the invention of computers and start of information distribution, to (5) today's super smart society [17].

Technological development advanced rapidly, especially since the Industrial Revolution at the end of the 18th century [18]. Industrial development has progressed since the 1st industrial revolution after the introduction of water- and steam-powered mechanical manufacturing facilities, the introduction of electrically powered mass production and development of the division of labor during the second industrial revolution, development of electronics and IT technologies intended for further automation of manufacturing during the third industrial revolution, the introduction of cyber-physical systems during the fourth industrial revolution, to the fifth industrial revolution that "incorporated new technologies in all industries and several social activities to solve problems related to economic development and social issues" [19].

Human development has been equated with technological development that has been at the forefront of social development in the past $[1,19]$. The literature states that the basic reasons for such development include limited capacities for knowledge development, excess demand over offers on the market, dissatisfaction with the population's basic living needs, and the unlimited availability of natural resources [18,19].

Consequently, technological development has been considered separately from social issues [20]. In essence, this means that technological development was guided by economic development, which then led societal development [21]. Such societal development several scientists noted as "traditional societal development leading by technology" (see Figure 1). 


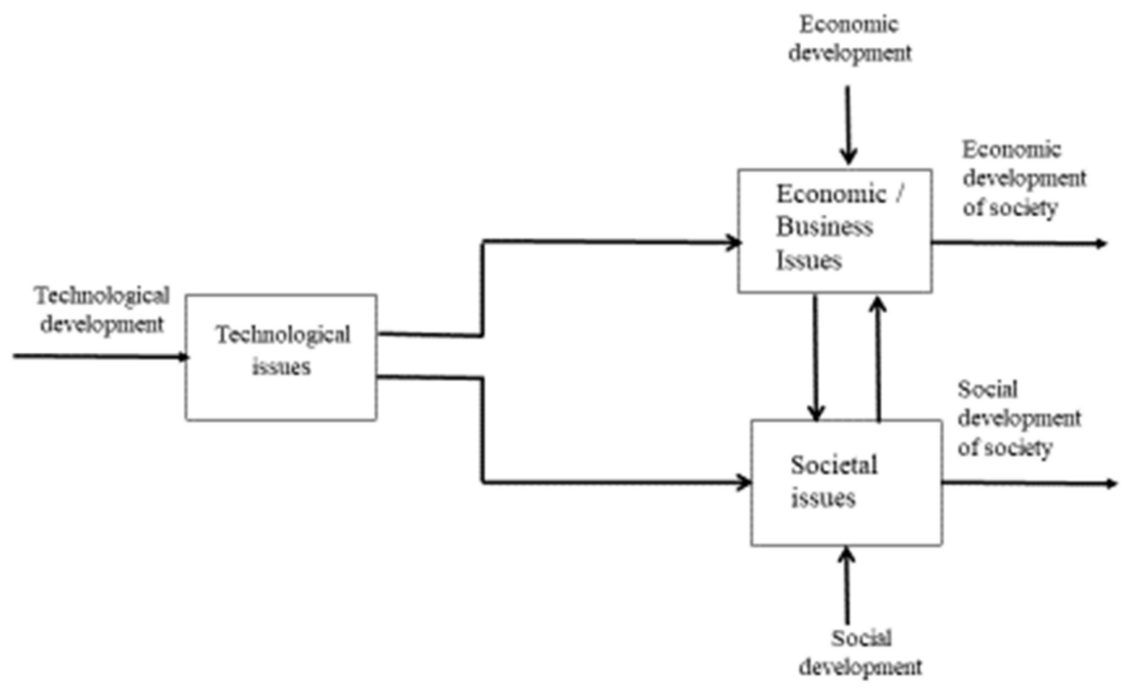

Figure 1. Traditional societal development.

The first more comprehensive attempts to research technological development by considering selected social issues were carried out in the context of sociotechnical theory in the 1940s [22,23]. Sociotechnical authors revealed the importance of the interrelatedness of social and technical aspects of an organization as preconditions for successful organizational performance and found that the optimization of only one aspect (socio or technical) caused unpredictable relationships, which can damage the system's performance [23,24].

In addition, the development of systems theory and cybernetics after the 1960s [12,20] also had a significant effect on a more comprehensive understanding and treatment of technology. Various systems theories and technical cybernetics have contributed to developing a set of methodological solutions for the study of complexity, integrity, and systemic treatment of technology and objective reality, which have enabled the development of newer technological visions in recent decades [20,22].

The development of contextual and methodological technological knowledge $[12,20]$ and growing societal requirements $[2,6]$ have enabled researchers to develop a range of modern technological concepts $[3,21]$ which then had a reciprocal impact on economic and social development. The literature describes such a managed development with the term "modern-technologically oriented social development" [12,21] (see Figure 2).

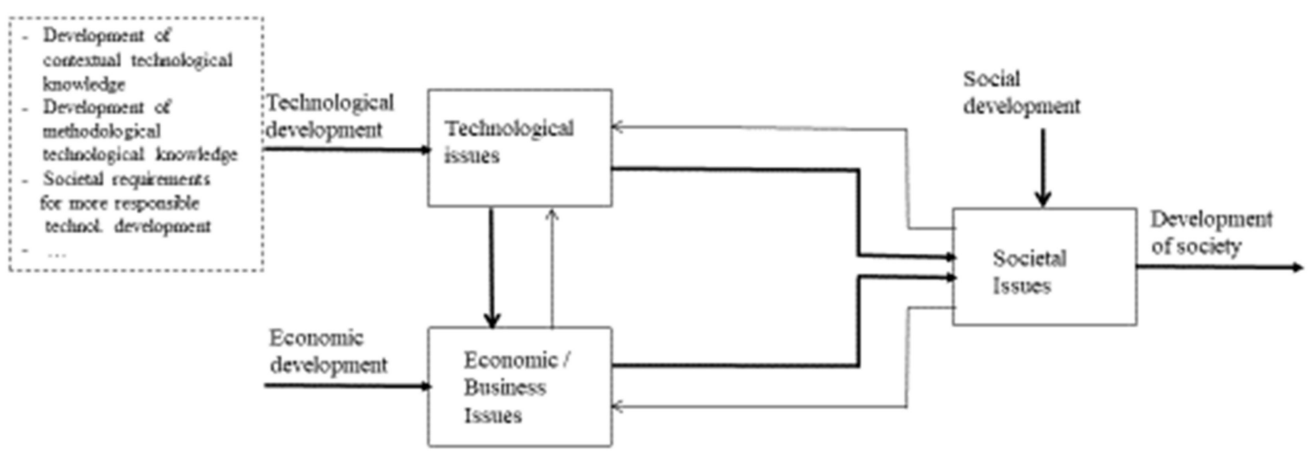

Figure 2. Modern technologically driven societal development.

Among modern technological concepts, the literature emphasizes the importance of Industry 4.0 [25]; "Industrial Internet" scheme [26]; "Made in China 2025" [27]; and Industry $5.0[28,29]$. Their broadened view of technology is based on various short- and long-term technological alternatives, changes, and solutions that also account for the goals of societal development [12,20]. 
The current transition from the information society to a super smart society in the framework of the fifth phase of the industrial revolution $[30,31]$ is based on technological development, which enables and provides a very powerful collection of data and information stored in physical space of classical databases as well as advanced directives for analyzing collected data and information [32]. However, at the same time, modern society still does not have technological solutions that would allow a high degree of convergence between cyberspace (virtual space) and physical space (real space); comprehensive connections between people, things, and systems and cyberspace; and the use of artificial intelligence for comprehensive treatment of collected data and appropriate solutions for the linking of artificial intelligence with humans [33,34].

From the point of view of our research, the basic advantages of newer technological concepts are mainly in their interdisciplinary study of technology and focus on the development of technologies intended for solving social problems, thus connecting previously divided technological and social studies of social development [35-37].

Despite the efforts and capabilities of society and organizations to attain more socially oriented technological development, modern society faces many substantive, methodological, and adaptive constraints on mechanisms and processes by which more responsible technological development and advanced technologies could be conceptualized into responsible behaviors of stakeholders and whole society [38,39].

\subsection{Meaning of Technology for Development of CSR}

The development of humanity and its growing effect on the natural environment has led to the development of nature conservation movements [6,8] and initiated environmental research $[10,40]$. Additionally, the rapid social development of society has increased people's awareness of the need for and importance of more responsible relations with nature and the community in which they live [41,42]. All of this led scientists to develop new visions for more responsible behavior at all levels of human life, such as responsible development, sustainable development, and green development [6,8].

Issues of a more responsible attitude of people toward their important environments were considered in various scientific fields $[43,44]$. Environmentalists played a central role in the development of the response operation. They defined the starting points, developed foundational theories, and proposed basic models to be implemented in different areas of society [6,32]. Researchers from social sciences, such as sociology, management, and economics, have tried to address the challenges of implementing responsible operation in organizations and guiding the implementation of these concepts in individual areas of human activities $[45,46]$. Researchers in behavioral sciences have also contributed to the development of responsible concepts, creating a contextual and methodological basis for understanding responsible behavior and ways to achieve it [47,48]. This field is least discussed in the technological sciences, where researchers have focused on dealing with the direct effects of individual technological solutions on the natural environment and systems for measuring these effects [31,42], which are still completely separate from research in other sciences.

Such a research approach raises many questions about the need for more multidisciplinary and multifunctional research on the attitudes of people and their organizations toward important environments $[48,49]$ and especially about the role and importance of technological development for the further development of humankind [20,30].

As a part of research on environmental responsibility, scientists have paid great attention to the responsible operation and behavior of organizations that represent the most influential subjects of modern society and also have the greatest effect on the natural environment [6,7]. Among the concepts developed for more responsible organizations, we focus on the predominant concept of CSR in literature in the 1960s [7,10]. With CSR, scientists wanted to expand the interest of organizations in making profits for shareholders with interests to protect natural, social, and economic environments in their forming of responsible orientation $[15,19]$. These areas also form the basic dimensions of the predom- 
inant model of CSR and the literature: the triple-bottom model of CSR [6,8]. Theorists and practitioners use this model to analyze individual dimensions and correlations between dimensions of CSR [40,42] and mechanisms guiding the responsible behavior of organizations $[6,10]$.

In modern society, care for the environment is generally accepted, highly valued, increasingly normatively supported [50,51], and oriented toward better protection of the environment in the future by reducing the exploitation of limited available natural resources and eliminating natural devastation in the past [52,53]. The consideration of the environmental dimension of CSR in an organization determines several external factors, such as political, legal, and behavioral orientations, policies, and normative legislation [6,10].

However, organizations are relatively autonomous entities of society and can more or less follow the recommendation of the external environment in their environmental orientation [8,32]. Thus, organizations can direct their efforts to achieve different levels of environmental responsibility, from compliance with legal provisions to proactive environmental protection $[6,10]$. Therefore, the environmental orientation of organizations is significantly influenced by internal factors, among which the literature highlights the organization's perception of the importance of environmental protection, the achieved responsibilities of organizational stakeholders, and market factors [11,15].

The environmental dimension of CSR is particularly determined by the organization's perception of the relative importance of the ecological environment $[42,45]$ and the organization's assessment of the sustainability of organizational operation and behavior to achieve ecological goals [8,54]. Another important factor is the development of awareness of the need to protect nature among stakeholders of the organization, as their moral commitment to responsible internal and external behavior, and to meet generally accepted social expectations $[48,50]$. Shareholders and managers play an important role in this development and their coordination of interests and goals, such as short-term and long-term goals, social and economic goals, and partial and common goals [55,56]. In addition, conditions in the modern market may importantly increase the interests of organizations in environmental care $[8,57]$. Thus, in recent years, market opportunities for products and services intended for environmental protection related to recycling, conservation, or managing wastes; the use of clean or natural friendly technologies for the reduction of greenhouse gas emissions, responsible production, and reduced loss of foodstuffs [31,32]; and goods that have no harmful consequences for users, such as healthy and natural products [14,22], have been growing due to prevailing society's focus on protecting nature.

The social dimension of CSR is determined by the organization's perception of the relative importance of the expected social roles and norms in the environment [7,42] and organizational assessment of the suitability of organizational operating and behavior to achieve the applicable social principles of the environment $[2,10]$. The social literature additionally explains CSR as the level of organizational support for actions that lead to some social good "beyond the firm's interests and that which is required by law" ([53], p. 605). Thus, with social orientation, organizations try to reduce social, business, and legal risk by adapting their business to the expected or normatively determined social requirements and needs of the environment in which they operate [52,58].

When addressing the social dimension, many questions are open related to social goals and the level of their achievement in organizations [2,11]; for example, the environment expects modern organisms to actively participate in solving urgent social problems, such as labor relations, relations between people in society, development issues of society, growing demands for energy and foodstuffs, poverty alleviation, and equal development opportunities, to name just a few [31,36]. At the same time, the importance of social goals in individual environments can vary greatly, which raises the question of choosing these goals for operating in the domestic or international environment $[39,57]$. In addition, organizations are faced with a decision at what level and to what extent they want to achieve the selected goals, which leads to a selection of different strategies of social orientations 
from pursuing the prevailing environmental goals to focusing on achieving goals that exceed current social expectations of the environment [41,48].

The economic dimension of CSR is determined by the organization's perception of the relative importance of achieving economic results and economic prosperity $[39,44]$ and organizational assessment of the economic adequacy of operation and behaviors to achieve economic goals $[57,59]$. It should be borne in mind that economic sustainability refers to the responsibility of economic action at societal and organizational levels $[39,57]$. Economic practice shows that most organizations follow the principles of the interventionism phase of the market economy in judging and evaluating their economic decisions and the economic expectations of others [6,52]. In this context, organizations are always developing a pragmatic understanding of economic development, which shifts the original focus from "profit maximization" to "responsible business" to achieve "more sustainable economic results of organizations" [39,57].

Researchers found that the sustainable economic orientation of organizations can increase, decrease, or not affect the economic results of organizations [6,39]. At the same time, research on the application of different economic policies and their effects on the organization's outcomes has yielded conflicting results $[56,57]$. Additionally, the literature does not report the effects of different levels of economic suitability on organizational results, making it even more difficult to understand the achievement of responsible economics in justifying the natural and social goals of organizations [38,59].

Analyzing the three basic dimensions of CSR is, directly and indirectly, related to issues of technological development and technologies in organizations [1,12]. Thus, studies of the social dimension of CSR include issues of choice and the use of technological orientations and technologies in the production of products and services that can protect the natural environment, eliminate excessive environmental degradation, and prevent future harmful effects on the environment and its participants [24,31]. At the forefront of recent discussions of the social dimensions of CSR are questions of the role of traditional and new advanced technologies in solving key social issues of modern society and their use to reduce the consequences of actual social problems [19,25]. Furthermore, the treatment of the economic dimension has in recent decades focused on the use of technologies that would allow responsibly balancing the achievement of economic results, viewed from a short-term perspective and self-interest of the most influential member of society, and long-term social benefits for the most members of organizations and society in general [22,32].

Following the studies of CSR and its dimensions [22,32] and more recent technological development $[8,16]$, we continue studying the relationships between technological and social development of organizations. Thus, in the context of our study, we posit:

RQ1: Extending the CSR model with a technological dimension can improve the future sustainable development of organizations.

\section{Technology and Corporate Social Responsibility}

\subsection{CSR in Slovenia}

The presented theoretical background for a broader understanding of technology for the achievement of CSR goals revealed various treatments of the problem under investigation and possible directions for their future consideration. We focus our analysis on organizations from Slovenia as a case of a country in which organizations evidenced a high level of CSR development among the European Union countries [60,61].

Slovenian organizations have recorded substantial improvement in the development of CSR after Slovenian independence in 1991 [62,63]. Thus, the European Commission reports a substantial improvement in the development of CSR among Slovenian organizations in the longer term perspective from 2001 to 2020 [60,62]. The result of the European Commission Growth Survey shows the rapid development of CSR of Slovenian organizations after 2011 and their further stable progress in implementing CSR [60,62] (EC, 2020). Even changes in the operating conditions of organizations in the last decade-especially 
the deterioration of the situation during the global economic crisis of 2009-did not reduce the stable increase of CSR in organizations [63,64].

Regardless of the progress achieved, empirical studies indicate several open issues regarding CSR's implementation in organizations and society [60,62]. For example, Nedelko et al. [64] revealed the strong orientation of managers on achieving CSR goals and additionally reported about the differences among companies from traditional and modern technology industries in achieving CSR goals. Potocan et al. [63] report large differences in the understanding of CSR between future managers in Slovenia and Lithuania and highlight the problem of differences in the understanding of CSR among Slovenian respondents with economic and technical education.

Previous research on the impact of technology and technological development on the state of CSR in Slovenian companies reported about diverse results [61,65]. Most empirical studies confirm the importance of modern technologies for the development of organizations in accordance with the needs and needs of society but without explicit consideration of CSR $[61,64]$. Only individual studies attempt to explain the cause-andeffect relationships between technology and CSR and indicate potential solutions for more holistic inclusion of technology and development of CSR [61,65]. Thus, Cresnar et al. [65], as part of the analysis of 323 Slovenian industrial companies, report about the most used management solutions for the development of readiness of manufacturing organizations for the implementation of Industry 4.0 and emphasize the importance of CSR in this context. The study by Waleed et al. [66] presents the importance and role of different management solutions for responsible operation in sustainable supply chains based on a comparative analysis of companies in North America, Western Europe, Arab countries, and Slovenia and highlights differences in achieving CSR goals between areas with various technological structure of companies. In addition, Potocan et al. [61] conceptualize proposals to improve contextual and methodological frameworks for a more comprehensive treatment of CSR in organizations based on the findings of the Society 5.0 development concept.

Studies on situations and trends in the development of CSR and the global environment [10,12] and the findings of Slovenian research on CSR $[61,62,65]$ present the content and methodological starting points for our formulation of proposals for improving CSR according with recommendations for the development of conceptual papers [67-69].

\subsection{Sustainability of Technology in Organizations}

Humankind's history is characterized by technological development, the monodisciplinary nature of which characterized most previous discussions on the role of technology in societal development [1]. However, the demands of the environment on organizations to align their technological development and function with social expectations of natural, social, and economic effects on society are further growing [5]. Researchers and organizations have responded to these demands by developing solutions to assess the effects of current technologies on natural and social environments $[4,6]$.

Different stakeholders have led the development of more comprehensive systems of sustainable indicators for technology from political organizations, such as the United Nations, European Union, Organization for Economic Cooperation and Development; professional organizations, such as the International Organization for Standardization, World Trade Organization; and interest groups, such as global report initiatives, universities, and professional associations [11,54], which have also actively supported their introduction and use in organizations to assess the sustainability of decisions related to the selection and use of production technologies [54,70-73].

Thus, most initial evaluation systems of technological sustainability include indicators that assess the significance and effect of individual technologies on various areas of the operation and behavior of organizations and their environment. Thus, environmental indicators were developed to assess technologies in terms of their emission, pollution, resource consumption, and natural habitat conservation [54,71]. Social indicators aim to assess the effect of technologies on the employee, customers, and community $[2,10]$. 
Finally, economic indicators aim to assess the effects of technologies on costs, profits, and investments in organizations $[47,57]$.

Despite the importance of initial systems of sustainable indicators, the literature states that their use still does not enable the desired comprehensive sustainable assessment of technological development and does not provide the necessary support for the further sustainable development of organizations and society as a whole [12,32].

Therefore, the development of the processing system of technologies has continued to form indicators for assessing the sustainability of technology's performance and indicators for assessing technological advancement in organizations [5,72]. The purpose of technological performance indicators is to assess further the conformity, policies, and programs of organizations intended to achieve the organization's objectives [31,33]. Conformance indicators aim to address the ability of organizations to follow certain guidelines for carrying out the manufacturing process according to valid standards and the objectives of organizations, including sustainability objectives $[12,70,73]$. Technology advancement indicators are designed to measure the use of technologies and the developmental research capability of organizations to use new technologies $[13,24]$. This group includes high-tech products indicators for assessing the number of new technologies that organizations implement to improve their operation and indicators of organizations' abilities and capabilities to introduce and use new technologies sustainably. Therefore, these groups of indicators are intended to provide a general overview of the operation and behavior of organizations, and they also make it possible to assess their three basic dimensions of sustainability [12,20].

The presented additional criteria have otherwise increased the integrity and quality of treatment of the sustainability of organizations, but the literature states that they are not sufficiently consistently defined and suitable for general use in most organizations [31,42].

Thus, the literature consistently suggests redesigning current indicator systems to assess the sustainability of the technologies themselves, the sustainability of the use of technologies, and the sustainability of the technological results [30,71]. However, such a transformation is associated with several contextual and methodological issues [20,22] that have not yet been thoroughly researched and clarified, neither at the level of organizations nor at the level of society as a whole $[6,37]$.

At the organizational level, the most up-to-date content of the indicators focuses on the sustainability of technological results, such as products and services [23,28]. In doing so, the research to date suggests that it would make sense to examine the sustainability of products, services, and their use [31,35]. However, this raises the question of the choice of criteria, the method of measuring the criteria, the location of measurement, their mutual relations, and, of course, their evaluation [23,36]. Additionally, there are questions about how to measure the proposed common criterion, given that it can relate only to the organization if the organization itself assesses the sustainability of the product, users in the environment, and the joint synergistic effect of both groups of indicators, which can differently affect the overall level of sustainability for considered the product or services [30,73].

The recent literature also suggests further substantive development of current indicators for measuring technological performance and the advancement of technology $[4,74]$. However, the current indicators of these areas measure the sustainability of organizations only indirectly; therefore, it would make sense to supplement them to address differences in sustainability between individual technologies, the sustainability of the implementation of processes in individual areas of organizations, and the sustainability of several various new technologies in organizations [30,75].

Proposals for supplementation repeatedly return to the fundamental substantive question of measuring technological sustainability comprehensively enough, which is especially unclear when evaluating the technologies themselves. No comprehensive system of criteria in the literature allows a sufficiently objective assessment of an individual technology compared to previous technologies or in comparison with other technologies at the same level of development. If the current system of criteria can be used at least in part to compare new and past (traditional) technologies, it does not allow for proper evaluation 
of all possible combinations of different technologies in the organization and does not cover the specific comparisons of technological sustainability among specific industries and areas of economic activity. Thus, past studies have usually cited examples of new technologies and, at the same time, assumed that they are also more sustainable compared to the technologies before them, which is not always true. The important questions in this area involve the following: how to assess the sustainable use of traditional technologies compared to the use of new technologies, how to assess the possibility of using different new technologies, and how to assess the sustainability of technologies that otherwise have the same overall effect on the sustainability of organizations.

\subsection{Technological and Further Sustainable Development}

Newer technological visions, such as Industry 4.0, the Industrial Internet scheme, and Society 5.0, are oriented toward the sustainability of technological development and individual technologies $[12,25]$. At the forefront of their research are mainly questions about the transition from the current situation to the future sustainable society $[3,16]$ and more comprehensive transdisciplinary and multifunctional understanding and study of technological progress for the future development of humankind $[17,21]$.

Several objective and subjective factors limit the sustainable grounded and leading technological development $[4,13]$. Most developments and the results of basic research in the natural sciences and the technological sciences cannot be objectively judged from their sustainability perspective. Thus, research in optics and laser technology cannot be judged from the perspective of their sustainability, while the level of their sustainability can be defined for different technological solutions [11,20]. Given the characteristics of the basic research itself and its course, we cannot predict their basic orientation toward sustainable development.

A partial exception is a technological development focused on sustainable (or more sustainable) technologies that would enable high sustainability of operations, products, and services of organizations in the future [32,35], which would enable the solution of current or future sustainable problems. However, for such technology-oriented development, society must define the future use of such technologies in society to identify the necessary development of technologies, infrastructure, or conditions for the future use of envisaged sustainable technologies as well as societal conditions facilitating its use [20,33]. A possible example is a development of the autonomous car (level 3) by Honda to increase the sustainability of transport [7], which triggered the development of car technologies themselves, the technological infrastructure for their use, and societal changes necessary for the cultural, legal, and social regulation of such transportation. At present, the environment's response to the infrastructural needs of organizations for their future use of sustainable technologies is still left to market mechanisms-especially the supply-demand relationship or the willingness of governments to accelerate sustainable technologies [21,22]. However, the question about the necessary development of new mechanisms by which companies could influence the targeted development of sustainable technologies or even increase the sustainable orientation of general technological development remains open $[3,13]$.

The second unresolved content is related to the transition from the current technological state to the future state of sustainable technological operation of organizations and society [16,71]. The course and speed of the transition are influenced by several factors, among which the literature highlights the development of awareness of the importance of sustainable development in society and the company's willingness to finance the introduction of sustainable technologies and the necessary environment for their use $[3,6]$. Therefore, the development policies of society significantly determine the organizations transition. Although most organizations prefer more sustainable technologies, they attend mainly to the sustainable use of different sustainable technologies [5,72]. At the same time, it is necessary to consider that most countries in the world set institutional requirements for at least the sustainable use of technologies in organizations, while more developed countries additionally require greater use of sustainable technologies in organizations $[20,36,70]$. 
In addition, research on the characteristics of available sustainable technologies in organizations and differences in their use between individual environments does not provide more comprehensive insight into individual combinations of diversified technologies and different levels of their sustainable implementation in production [33,35].

Most global, regional, and local organizations cite sustainable technological development and greater use of sustainable technologies as key goals for future development [2,3], emphasizing the importance of necessary social change (such as education and regulation) and increased innovation in society as preconditions for its achievement [20,29].

Researchers in the last decade have often mentioned the need for a more comprehensive study of technological issues within CSR to clarify the relationship between technology and the basic dimensions of CSR [2,4]. Thus, numerous environmental and management studies have suggested the possibility of the contextual inclusion of technology in the treatment of CSR [2,3] and the consequent extension of CSR models with the technological dimension of CSR [11,16]. However, researchers do not agree on the necessary scope of substantive treatment of the technological dimension of CSR, the choice of areas required for its comprehensive understanding, and the characteristics of the relationships between the technological dimension of CSR and the fundamental dimensions of CSR [11,21].

Research to date indicates the need to differentiate (1) new technologies from traditional and (2) sustainable technologies from completely unsustainable to completely sustainable through developing contextual and methodological solutions for their objective assessment [32,37]. Therefore, researchers do not include this issue directly in the CSR model but define it as part of the technological framework of CSR [16,33]. However, such a basic definition of technology characteristics is not within the organization's competence but takes place in the organization's environment based on selected and considered social criteria. Consequently, the subject of the technological dimension of CSR can be any selected technology that, regardless of its actual sustainability characteristics, represents a suitably sustainable technology for the organization.

Considering CSR's technological dimension, how the sustainability of individual technologies is addressed is another unresolved issue [20,22]. The decision to consider the sustainability of the technology, the sustainability of the implementation of the technology, or the sustainability of the technology results or their possible combination is within the competence of the organization but is largely determined by the characteristics of the technology, technological specifics of the organization, and market position of the organization $[24,30]$. Thus, researchers propose addressing the overall sustainability of technology, several areas of its sustainability, or an individual selected area of sustainability [2,3].

The research results agree about the importance of the technological dimension compared to other dimensions of CSR $[3,6]$. Thus, most researchers assume that the technological dimension has the same significance for CSR development as other dimensions of CSR that are based on an interdisciplinary and multifunctional understanding of technological development and technologies [12,14].

Based on the findings on sustainable development $[7,8]$, the role of technological development for the development of CSR [5,70], and the findings of past research [24,37,72], we proposed a comprehensive model of sustainable organizational development, as shown in Figure 3. 


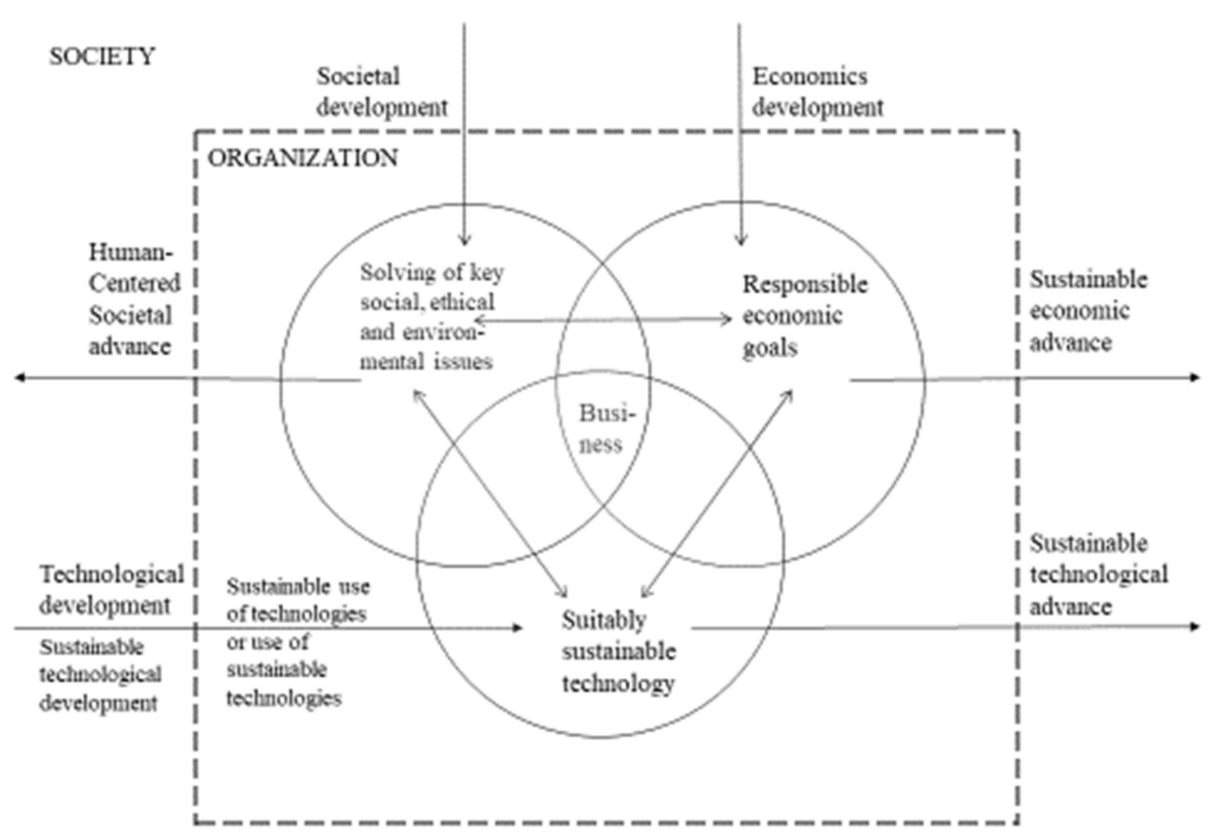

Figure 3. Comprehensive model organizational sustainable development.

\section{Conclusions}

Technology remains the basic driver of societal development, but growing social expectations place new demands on technology developers of responsible and sustainable technologies that could adequately support the solution of social issues in modern society and ensure the survival of humanity in the long run based on sustainable development of society $[11,12]$.

Therefore, researchers and organizations have focused on studying technology for the advancement of CSR and, in this context, mainly analyzing how exactly the newest technological development and new technologies can affect the sustainable orientation of organizations and CSR $[15,20]$. As scholars have revealed [8,13], the main shortcoming of the current research of cause-and-effect links of technological and sustainable development of organizations is mainly in the lack of integrity of CSR treatment and disregard for multifunctionality and interdisciplinarity issues from this field [2,70]. In the last decade, several researchers focused their attention on comprehensive consideration of technologies in the context of CSR, including issues of the use of different manufacturing technologies on sustainable operating, different ways of sustainably using available technologies, and the development of new sustainable technologies [70-72].

In this context, the authors, primarily from the technological field, have focused on assessing the effects of organizational technology on the environment and society $[5,8]$. This led to the development of sustainable indicators of technology-led international organizations, although the literature indicates that major sustainable technology indicators are still inconsistently defined and unsuitable for use in different organizations [54,72]. Consequently, the literature highlights several attempts to create broader systems of indicators of technological problems that can supplement the assessment of the basic dimensions of CSR and, in doing so, assess the sustainability of technologies, their implementation, and their results $[3,12]$.

Environmentalists and social researchers have focused on the possibilities of more sustainable use of technologies in society, and especially in organizations, based on the findings of newer technological visions developed in recent decades [14,16]. Their purpose was to overcome the traditional separate treatment of technological and social development by focusing on developing and using technologies that would enable social issues related to environmental protection and the more sustainable development of society. 
Despite the importance of past knowledge about sustainably oriented technological development possibilities, the current developmental approaches do not sufficiently encourage the content development of sustainable technologies and related technological solutions [12,27]. Therefore, in the last decade, an increasing number of calls have been made to develop sustainable technologies and integrate their treatment into sustainable development [5,9]. Thus, a substantive and methodological extension of leading CSR models with the interdisciplinary and multifunctional treatment of sustainable technologies is needed.

In terms of previous research on the more comprehensive involvement of technology in the treatment of CSR, we can highlight the authors' common conclusion that technological development is becoming so important for the operation of modern organizations that it can no longer be considered separately from other aspects of business [9,70]. However, there is less uniformity among researchers regarding the mechanisms of the impact of technology on the sustainable development of organizations, which is mainly due to the diversity of existing technologies and the diversity of their sustainable potential [3,71,72]. Therefore, numerous studies suggest dividing the treatment of this issue into the sustainable use of technologies - regardless of their actual sustainable orientation, and the separate treatment of technologies with different degrees of actual sustainable orientation-i.e., traditional, newer, and sustainable technologies [11,72]. Such technology differentiation has made it possible to improve the treatment of the impact of technology on CSR, but the question of subjective criteria for assessing the sustainability of technologies and their impact on CSR and the sustainable development of society remains open [5,71]. How to assess the sustainable orientation of different technologies, how to assess technologies with different impacts on individual dimensions of CSR, and how the use of the same technology affects CSR in different environments are just some of the open questions, which depend on societal criteria and broader global agreement on desired goals and the dynamics of development into a sustainable society [1,13].

The study has several theoretical and practical implications. The breakthrough contribution of this study is the realization of the importance of changing technological development due to the growing needs and demands of society to solve the social problems of modern society. This study further explored the role of technological development in further sustainable societal development $[6,21]$. We studied and contributed to sustainable literature with insights into the effects of technological development on CSR advancement. Among the practical implications is the forefront inclusion of technology in the treatment of CSR and the sustainable development of society as a whole. This implies that more attention should be given to the interdisciplinary and multifunctional consideration of development and technological advancement in modern society. This further implies that we need to change our understanding of technology and its importance in the development of society.

This research also has some limitations. First, by considering relationships between technological over sustainable developments, we did not comprehensively examine the specifics of individual technologies and their use in different organizations $[1,16]$. Second, the research results represent only general trends and patterns of the relationship between technology and CSR, which is an additional contextual limitation of the research. Third, an important limitation is the use of the applied methodological approach based on multidisciplinary and multifunctional research on the effects of technology on CSR, which would be possible to investigate by using different methodological approaches.

Future studies should test these research findings empirically, generating further research on the connections between specific technologies and the sustainable development of various organizations. Thus, it would be necessary to replicate our findings with samples from similar companies, different companies, and companies from different backgrounds operating in diverse conditions or situations. Future methodological research on the topic could compare different research approaches with our methodological approach. In addition, it would be useful to establish methodological starting points for the development 
of new indicators of sustainability and a more comprehensive system of indicators of the organization's sustainability that would address the technological dimension of CSR more comprehensively. Another possible research direction would involve studying the relationships of environments with different levels of development and diversified situational conditions with their use of sustainable technologies in organizations.

Funding: The author acknowledges the project "Entrepreneurship for Innovative Society" (P5-0023) (financially supported by the Slovenian Research Agency).

Institutional Review Board Statement: Not applicable.

Informed Consent Statement: Not applicable.

Data Availability Statement: Data are not available.

Conflicts of Interest: The authors declare no conflict of interest.

\section{References}

1. Corsi, A.; Pagani, R.N.; Kovaleski, J.; Luiz da Silva, V. Technology Transfer for Sustainable Development: Economic Impacts Depicted and Some Other Answers to a Few Questions. J. Clean. Prod. 2020, 245, 118522. [CrossRef]

2. Aguilera, R.V.; Rupp, D.E.; Williams, C.A.; Ganapathi, J. Putting the S Back in Corporate Social Responsibility: A Multilevel Theory of Social Change of Organizations. Acad. Manag. Rev. 2007, 32, 836-863. [CrossRef]

3. Kemp, R. Technology and the Transition to Environmental Sustainability: The Problem of Technological Regime Shifts. Futures 1994, 26, 1023-1046. [CrossRef]

4. Healy, S. Science, Technology and Future Sustainability. Futures 1995, 27, 611-625. [CrossRef]

5. Managi, S.; Lindner, R.; Stevens, C. Technology Policy for the Sustainable Development Goals: From the Global to the Local Level. Technol. Forecast. Soc. Chang. 2021, 162, 120410. [CrossRef]

6. $\quad$ Elkington, J. Enter the Triple Bottom Line. In The Triple Bottom Line: Does It All Add Up; Henriques, A., Richardson, J., Eds.; Earthscan: London, UK, 2004; pp. 1-16.

7. Aguinis, H. Organizational Responsibility: Doing Good and Doing Well. In APA Handbook of Industrial and Organizational Psychology; Zedeck, S., Ed.; American Psychological Association: Washington, DC, USA, 2011; Volume 3, pp. 855-879.

8. Carroll, A. Corporate Social Responsibility: Evolution of a Definitional Construct. Bus. Soc. 1999, 38, 268-295. [CrossRef]

9. Rego, A.; Cunha, M.P.; Polonia, D. Corporate Sustainability: A View from the Top. J. Bus. Ethics 2017, 143, 133-157. [CrossRef]

10. Carroll, A.; Shabana, K. The Business Case for Corporate Social Responsibility: A Review of Concepts, Research and Practice. Int. J. Manag. Rev. 2010, 12, 85-105. [CrossRef]

11. Wang, H.; Tong, L.; Takeuchi, R.; George, G. Corporate Social Responsibility: An Overview and New Research Directions: Thematic Issue on Corporate Social Responsibility. Acad. Manag. J. 2016, 59, 534-544. [CrossRef]

12. Hansson, S. Technology and the Notion of Sustainability. Technol. Soc. 2010, 32, 274-279. [CrossRef]

13. Secundo, G.; Ndou, V.; Del Vecchio, P.; De Pascale, G. Sustainable Development, Intellectual Capital and Technology Policies: A Structured Literature Review and Future Research Agenda. Technol. Forecast. Soc. Chang. 2020, 153, 119917. [CrossRef]

14. Cooper, R.; Foster, M. Sociotechnical Systems. Am. Psychol. 1971, 26, 467-474. [CrossRef]

15. Glavas, A. Corporate Social Responsibility and Organizational Psychology: An Integrative Review. Front. Psychol. 2016, 7, 1-13. [CrossRef] [PubMed]

16. Palazzeschi, L.; Bucci, O.; Di Fabio, A. Re-Thinking Innovation in Organizations in the Industry 4.0 Scenario: New Challenges in a Primary Prevention Perspective. Front. Psychol. 2018, 9, 1-30. [CrossRef]

17. Japan Business Federation (Keidanren). Toward Realization of the New Economy and Society. Reform of the Economy and Society by the Deepening of "Society 5.0"; Keidanren: Tokyo, Japan, 2016.

18. European Commission (EC). Germany: Industrie 4.0. Digital Transformation Monitor; European Commission: Brussel, Belgium, 2017, Available online: https:/ / ec.europa.eu/growth/tools-databases/dem/monitor/sites/default/files/DTM_Industrie\%204.0.pdf (accessed on 15 March 2021).

19. Higashihara, T. A Search for Unicorns and the Building of "Society 5.0"; World Economic Forum: Davos, Switzerland, 2018.

20. Savaget, P.; Geissdoerfer, M.; Kharrazi, A.; Evans, S. The Theoretical Foundations of Sociotechnical Systems Change for Sustainability: A Systematic Literature Review. J. Clean. Prod. 2019, 206, 878-892. [CrossRef]

21. Ruttan, V. Induced Innovation, Evolutionary Theory and Path Dependence: Sources of Technical Change. Econ. J. 1997, 107, 1520-1529. [CrossRef]

22. Zwaan, A. The Socio-Technical Systems Approach: A Critical Evaluation. Int. J. Prod. Res. 1975, 13, 149-163. [CrossRef]

23. Pasmore, W.; Francis, C.; Haldeman, J.; Shani, A. Sociotechnical Systems: A North American Reflection on Empirical Studies of the Seventies. Hum. Relat. 1982, 35, 1179-1204. [CrossRef]

24. Guo, M.; Nowakowska-Grunt, J.; Gorbanyov, V.; Egorova, M. Green Technology and Sustainable Development: Assessment and Green Growth Frameworks. Sustainability 2020, 12, 6571. [CrossRef] 
25. Federal Ministry of Education and Research (BMBF). The High-Tech Strategy for Germany; Federal Ministry of Education and Research: Berlin, Germany, 2010, Available online: http:/ / www.inovasyon.org/pdf/Germany.HighTechStrategy.pdf (accessed on 15 March 2021).

26. Annunziata, M.; Evans, P. The Industrial Internet@Work; General Electric Company: Boston, MA, USA, 2013, Available online: https://www.ge.com/sites/default/files/GE_IndustrialInternetatWork_WhitePaper_20131028.pdf (accessed on 15 March 2021).

27. State Council of People's Republic of China (SC). The Made in China 2025; State Council of People's Republic of China: Beijing, China, 2015.

28. Council for Science, Technology and Innovation (SCTI). Society 5.0; Ministry of Sciences and Technology: Tokyo, Japan, 2016, Available online: https:/ / www8.cao.go.jp/cstp/english/society5_0/index.html (accessed on 15 March 2021).

29. Japan Business Federation (Keidanren). Society 5.0 for SDGs; Keidanren: Tokyo, Japan, 2019.

30. Hansmeier, H.; Schiller, K.; Rogge, K. Towards Methodological Diversity in Sustainability Transitions Research? Comparing Recent Developments (2016-2019) with the Past (Before 2016). Environ. Innov. Soc. Transit. 2021, 38, 169-174. [CrossRef]

31. Foray, D.; Grubler, A. Technology and the Environment: An Overview. Technol. Forecast. Soc. Chang. 1996, 53, 3-13. [CrossRef]

32. Weaver, P.; Jansen, G.; Grootveld, E.; Spiegel, P. Sustainable Technological Development; Routledge: London, UK, 2017.

33. Dao, V.; Langella, I.; Carbo, J. From Green to Sustainability: Information Technology and an Integrated Sustainability Framework. J. Strateg. Inf. Syst. 2011, 20, 63-79. [CrossRef]

34. Brunswicker, S.; Chesbrough, H. The Adoption of Open Innovation in Large Firms. Res. Technol. Manag. 2018, 61, 35-45. [CrossRef]

35. Kumar, G.; Kim, S.-H.; Lay, C.H.; Ponnusamy, V. Recent Developments on Alternative Fuels, Energy and Environment for Sustainability. Bioresour. Technol. 2020, 317, 124010. [CrossRef]

36. Nakanishi, H. Modern Society Has Reached Its Limits. Society 5.0 Will Liberate Us; World Economic Forum: Davos, Switzerland, 2019.

37. Shiroishi, Y.K.; Uchiyama, K.N.; Suzuki, N. Society 5.0: For Human Security and Well-Being. Computer 2018, 51, 91-95. [CrossRef]

38. Windsor, D. Corporate Social Responsibility: Three Key Approaches. J. Manag. Stud. 2006, 43, 93-114. [CrossRef]

39. Crifo, P.; Forget, V. The Economics of Corporate Social Responsibility: A Firm-Level Perspective Survey. J. Econ. Surv. 2015, 29, 112-130. [CrossRef]

40. Dahlsrud, A. How Corporate Social Responsibility is Defined: An Analysis of 37 definitions. Corp. Soc. Responsib. Environ. Manag. 2008, 15, 1-13. [CrossRef]

41. Bowen, H. Social Responsibilities of the Business-Man; Harper: New York, NY, USA, 1953.

42. Dunlap, R.; Gallup, G.; Gallup, A. Of Global Concern: Results of the Health of the Planet Survey. Environment 1993, 35, 7-39. [CrossRef]

43. Hubert, A. Empowering People, Driving Change: Social Innovation in the European Union; Bureau of European Policy Advisers: Brussels, Belgium, 2010.

44. Jensen, M. Value Maximization and the Corporate Objective Functions. In Breaking the Code of Change; Beer, M., Nohria, N., Eds.; HSB Press: Boston, MA, USA, 2000; pp. 37-57.

45. Aupperle, K.; Carroll, A.; Hatfield, J. An Empirical Examination of the Relationship between Corporate Social Responsibility and Profitability. Acad. Manag. J. 1985, 28, 446-463.

46. Campbell, J. Why Would Corporations Behave in Socially Responsible Ways? An Institutional Theory of Corporate Social Responsibility. Acad. Manag. Rev. 2007, 32, 946-967.

47. Minton, E.; Khale, L. Belief Systems, Religion, and Behavioral Economics; Business Expert Press: New York, NY, USA, 2014.

48. Shen, J.; Benson, J. When CSR Is a Social Norm. How Socially Responsible Human Resource Management Affects Employee Work Behavior. J. Manag. 2016, 42, 1723-1746.

49. Whetten, D. What Constitutes a Theoretical Contribution? Acad. Manag. Rev. 1989, 14, 490-495. [CrossRef]

50. Kish-Gephart, J.; Trevino, L.; Chen, A.; Tilton, J. Behavioral Business Ethics: The Journey from Foundations to Future. In Business Ethics, Business and Society 360; Wasieleski, D., Weber, J., Eds.; Emerald: Bingley, UK, 2019; pp. 3-34.

51. Kassin, S.; Fein, S.; Markus, H. Social Psychology; Cengage Learning: Belmont, MA, USA, 2017.

52. Petrenko, O.; Aime, F.; Ridge, J.; Hill, A. Corporate Social Responsibility or CEO Narcissism? CSR Motivations and Organizational Performance. Strateg. Manag. J. 2016, 37, 262-279. [CrossRef]

53. McWilliams, A.; Siegel, D. Corporate Social Responsibility and Financial Performance: Correlation or Misspecification? Strateg. Manag. J. 2000, 21, 603-609. [CrossRef]

54. Joung, C.; Carrell, J.; Sarkar, P.; Feng, S. Categorization of Indicators for Sustainable Manufacturing. Ecol. Indic. 2013, 24, 148-157. [CrossRef]

55. Friedman, M. The Social Responsibility of Business Is to Increase Its Profits. N. Y. Times Mag. 1970, 13, $122-124$.

56. Gregory, P.; Stuart, R. Comparing Economic Systems in the Twenty-First Century; South Western: Mason, OH, USA, 2004.

57. Kitzmueller, M.; Shimshack, J. Economic Perspectives on Corporate Social Responsibility. J. Econ. Lit. 2012, 50, 51-84. [CrossRef]

58. Gelfand, M.J.; Aycan, Z.; Erez, M.; Leung, K. Cross-Cultural Industrial Organizational Psychology and Organizational Behavior: A Hundred-Year Journey. J. Appl. Psychol. 2017, 102, 514-529. [CrossRef] [PubMed]

59. Waddock, S.; Graves, S. The Corporate Social Performance-Financial Performance Link. Strateg. Manag. J. 1997, 18, 303-319. [CrossRef] 
60. European Commission. Country Report Slovania 2020 (Commison Staff Working Document); European Commission: Brussel, Belgium, 2017, Available online: https:/ / ec.europa.eu/info/sites / files /2020-european-semester-country-report-slovenia-en.pdf (accessed on 15 March 2021).

61. Potocan, V.; Mulej, M.; Nedelko, Z. Society 5.0: Balancing of industry 4.0, Economic Advancement and Social Problems. Kybernetes Int. J. Syst. Cybern. 2020, 492X, 1-18. [CrossRef]

62. Potocan, V.; Nedelko, Z.; Peleckiene, V.; Peleckis, K. Values, Environmental Concern and Economic Concern as Predictors of Enterprise Environmental Responsiveness. J. Bus. Econ. Manag. 2016, 17, 685-700. [CrossRef]

63. Potocan, V.; Mulej, M.; Nedelko, Z. How Economic Crises Effect Employees' Attitudes towards Socially Responsible Behaviour -Case of Slovenia. East Eur. Manag. Stud. 2019, spec. iss., 152-178.

64. Nedelko, Z.; Peleckiene, V.; Peleckis, K.; Peleckis, K.; Lapinskiene, G.; Potocan, V. The Impact of Economic Attitudes on Natural and Social Corporate Responsibility-A Comparative Study of Lithuania and Slovenia. Inžinerinae Ekon. 2019, 30, 362-372. [CrossRef]

65. Cresnar, R.; Potocan, V.; Nedelko, Z. Speeding Up the Implementation of Industry 4.0 with Management Tools: Empirical Investigations in Manufacturing Organizations. Sensors 2020, 20, 3469. [CrossRef] [PubMed]

66. Rashad, W.R.; Lazanyi, K.; Potocan, V.; Nedelko, Z. How Does Business Orientation of Manufacturing Enterprises Define the Utilisation of Lean Production? Acta Polytech. Hung. 2020, 17, 7-26. [CrossRef]

67. Whetten, D.; Clark, S. An Integrated Model for Teaching Management Skills. J. Manag. Educ. 1996, 20, 152-181. [CrossRef]

68. Whetten, D.; Felin, T.; King, B. The Practice of Theory Borrowing in Organizational Studies: Current Issues and Future Directions. J. Manag. 2009, 35, 537-563. [CrossRef]

69. Podsakoff, P.; MacKenzie, S.; Podsakoff, N. Sources of Method Bias in Social Science Research and Recommendations on How to Control It. Annu. Rev. Psychol. 2012, 63, 539-569. [CrossRef]

70. Cera, A. The Technocene or Technology as (Neo)Environment. Techné. Res. Philos. Technol. 2017, 21, 243-281. [CrossRef]

71. Bisong, P.; Apologun, S. Technology Can Save the Environment. Int. J. Humanit. Manag. Soc. Sci. 2020, 3, 11-19. [CrossRef]

72. Zhang, Y.; Sun, J.; Yang, Z.; Wang, Y. Critical Success Factors of Green Innovation: Technology, Organization and Environment Readiness. J. Clean. Prod. 2020, 264, 121701. [CrossRef]

73. Organisation for Economic Co-operation and Development (OECD). The Measurement of Scientific and Technological ActivitiesProposed Guidelines for Collecting and Interpreting Technological Innovation Data (Oslo Manual); OECD: Oslo, Norway, 2005.

74. Agarwal, R.; Prasad, J. A Conceptual and Operational Definition of Personal Innovativeness in the Domain of Information Technology. Inf. Syst. Res. 1998, 9, 204-215. [CrossRef]

75. Armbruster, H.; Bikfalvib, A.; Kinkela, S.; Lay, G. Organizational Innovation: The Challenge of Measuring Non-Technical Innovation in Large-Scale Surveys. Technovation 2008, 28, 644-657. [CrossRef] 